\title{
NATURAL DISASTERS VULNERABILITY ASSESSMENT OF GONDIA DISTRICT, MAHARASHTRA, INDIA USING DTM \& GIS TECHNIQUES
}

\author{
Devendra Pandey ${ }^{1}$, Yaswant B. Katpatal ${ }^{2}$, Pradeep P. Kundal ${ }^{3}$ \\ ${ }^{I}$ Professor, Department of Civil Engineering, Manoharbhai Patel Institute of Engineering \& Technology, Gondia, \\ India. \\ ${ }^{2}$ Professor Department of Civil Engineering, VNIT, Nagpur, India \\ ${ }^{3}$ Professor \& Head, Dept. of Geology, RTM Nagpur University, Nagpur, India
}

\begin{abstract}
The present paper deals with natural disasters assessment because they are unavoidable and cause huge damage to life and property. Though they cannot be avoided but they can be minimized. Out of these the major cause of concern is the flood. It is solely responsible for the loss of life and property and casualties. About 10\% of the population (119492 human lives) is affected by flood as per the 2011 census of Gondia District every year. The main aims and objectives study is to identify Annually Flooded Area, sort and model a solution to fight the causes of natural disasters and minimize its impact on human lives as well as the Natural Hazards Vulnerability Assessment of Gondia District using Met-lab and GIS technique.
\end{abstract}

Keywords: Natural Hazards Vulnerability Assessment (NVA), River Board Association (RBA), Annually Flooded Area (AFA). World Geodetic System 1984 (WGS 84), Digital Terrain Modeling (DTM)

\section{INTRODUCTION}

India's geo-climatic conditions as well as its high degree of socio-economic vulnerability, makes it one of the most disaster prone countries in the world. A disaster is an extreme disruption of the functioning of a society that causes widespread human, material, or environmental losses that exceed the ability of the affected society to cope with its own resources. Disaster is an event or series of events, which gives rise to casualties and damage or loss of properties, infrastructures, environment, essential services or means of livelihood on such a scale which is beyond the normal capacity of the affected community to cope with. Disaster is also sometimes described as a "catastrophic situation in which the normal pattern of life or eco-system has been disrupted and extra-ordinary emergency interventions are required to save and preserve lives and or the environment" [1-5]. Disasters are classified as "natural" disasters, or "man-made" disasters. Floods, droughts, tidal waves and earthquakes are considered as "natural disasters" while disasters caused by chemical or industrial accidents, environmental pollution, transport accidents and political unrest are classified as "man-made" disasters.

RBA in 1980 assessed the flood affected area in the country as 40 mha (Govt. of India, 2011). The sum of maxima of flood affected areas in any year considered by RBA up to 1978 as 33.516 mha has gone up to 49.815 mha by 2010 . However, there is no credible data base maintained by the States as required by a judicious criteria based on frequency of flooding, duration \& depth of inundation etc. The flood damages reported by States from 1953 to 2010 have been projected at 2011 price level as Rs. 81250 Billion approximately. (Government of India Planning Commission, Report of Working Group on Flood Management and Region Specific Issues for XII Plan, New Delhi October, 2011)

Gondia district occupies about $1.76 \%$ of the total area in the northeast corner of Maharashtra state lying between the north latitudes of $20^{\circ} 39^{\prime}$ and $21^{\circ} 38^{\prime}$ and east longitudes of $89^{\circ} 27^{\prime}$ to $82^{\circ} 42^{\prime}$. The plateau terrain, different grades of soil, extreme climatic conditions, many rivers and rich biodiversity Gondia district displays nature's variety. The main river, Waingangā River, flows from the northern boundary of the district. Waingangā's main tributary is the Bagh, which flows from the north-east parts of the district. Waingangā River's other tributaries the Bawanthadi, Pangoli, Chulband and Gadhavi are the other rivers in the district. The district is dotted with dams of which the largest dam is Itiadoh, with a capacity of 318 cum on the river Gadhavi in Arjuni-Morgaon Tahsil. Apart from this there are many large dams such as Shirpur, Pujaritola, and Kalisarad as well as smaller dams at Katangi, Chulband, Khairwandha, Chorakhmara and Bodalkasa [6-9].

\subsection{Climatic Condition}

Gondia experiences extreme variations in temperature with very hot summers and very cold winters and it has an average relative humidity of 62 percent and records average rainfall more than $1200 \mathrm{~mm}$ each year in rainy season. During month of May daytime average temperatures will generally reach highs of around $46^{\circ} \mathrm{C}$ and at night the 
average minimum temperature drops down to around $28^{\circ} \mathrm{C}$. The highest recorded temperature in May has been $48^{\circ} \mathrm{C}$ and lowest recorded temperature $20^{\circ} \mathrm{C}[10]$.

\subsection{Rainfall of Gondia}

The highest rainfall in the district is around 1500-1600 mm [10]. The rain generally increases from the west towards the east. The rainfall south west monsoon constitutes about $90 \%$ of the annual normal rainfall. On an average, there are 60 rainy days in a year in the district.

Table 1 Showing Rainfall data of Gondia district.

\begin{tabular}{|c|c|c|c|c|c|c|c|}
\hline $\begin{array}{l}\text { YEAR } \\
\text { S. No. }\end{array}$ & \begin{tabular}{|l|} 
NAIIE OF \\
DISTRICT
\end{tabular} & 2006 & 2007 & 2008 & 2009 & 204 & 2011 \\
\hline 1 & G0NDIA & 476.7 & 919.0 & 1551.6 & 933.1 & 1227.6 & 44.9 \\
\hline 2 & G0REGA0 & & & 147.6 & 905 & \begin{tabular}{|l|l|}
1299.4 \\
\end{tabular} & 146.9 \\
\hline 3 & TIR0RA & & & 1263.6 & 867.6 & \begin{tabular}{|l|l|}
1320.8 \\
\end{tabular} & 403.4 \\
\hline 4 & $\begin{array}{l}\text { MOREGAON } \\
\text { ARJUNI }\end{array}$ & & & 1203.2 & 890.4 & 1954.2 & 1653.1 \\
\hline 5 & DE0RI & & & 451.9 & 870 & 1213 & 917.3 \\
\hline 6 & A.IGA0N & & & 1352.3 & 845 & 1371 & 1274 \\
\hline 7 & SALEKASA & & & 1412.8 & 947.6 & 1384.5 & 1374.2 .6 \\
\hline 8 & $\begin{array}{l}\text { SADAK } \\
\text { ARJUNI }\end{array}$ & & & 1373.4 & 148.2 & 1819.3 & 1142.5 \\
\hline \multicolumn{2}{|c|}{ TOTAL RAINFALL } & & & 4316.5 & 7366.9 & 11589.8 & 9521.8 \\
\hline \multicolumn{2}{|c|}{$\begin{array}{l}\text { AVERAGE } \\
\text { RAINFALL }\end{array}$} & & & 1239.5 & 920.8 & 1448.7 & 1190.2 \\
\hline
\end{tabular}

The highest rainfall in the district is around 1500-1600 mm [10] as shown in the Table 1 . The rain generally increases from the west towards the east. The rainfall south west monsoon constitutes about $90 \%$ of the annual normal rainfall. On an average, there are 60 rainy days in a year in the district.

\subsection{Wind}

Winds are generally light to moderate with some increase in the wind force during the latter part of the summer and monsoon months. During the monsoon season the wind blow mostly from directions between south-west and northwest. In the period October to February, the winds are mainly northerly to north-east in the morning and northeasterly to easterly in the afternoon. The minimum speed of wind is observed in the month of December that is $2 \mathrm{Km} / \mathrm{Hrs}$. and maximum speed is observed in the month of rainfall. Gondia District receives rainfall from SouthWestern winds mainly in the months of June, July, August and September. July and August are the months during which the maximum rainfall as well as maximum continuous rainfall occurs [11].

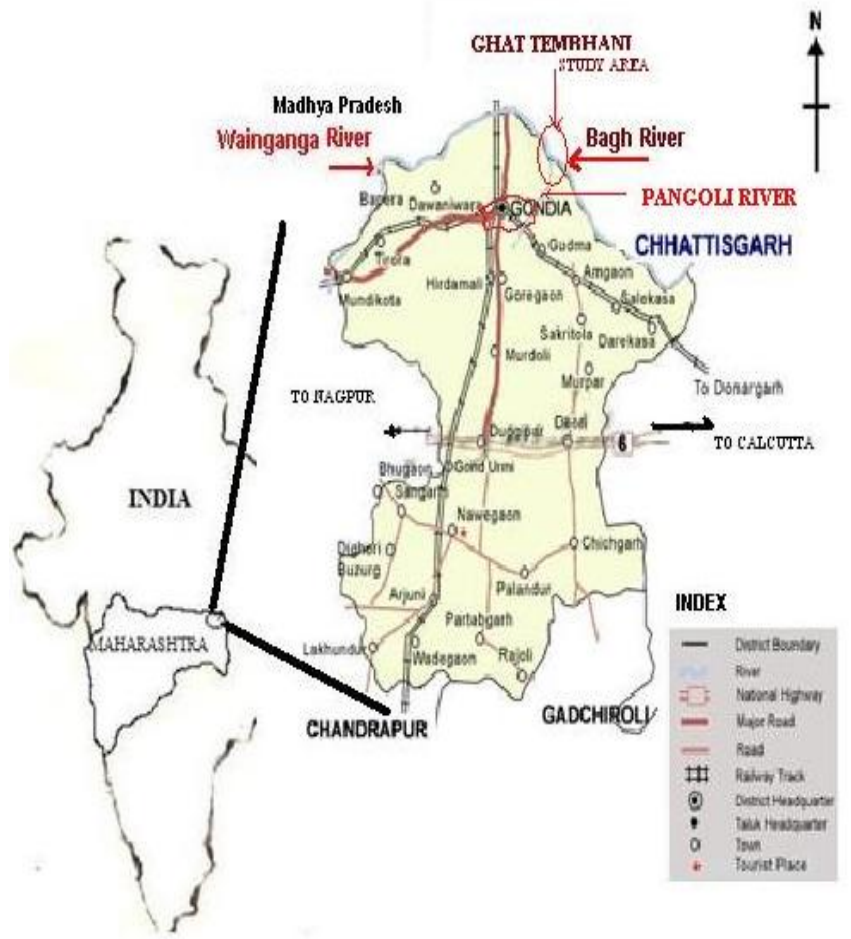

Fig 1 Showing Geographical Boundary of Study Area

\subsection{Disaster Overview of Gondia District}

Gondia district stretches over an area of $5641 \mathrm{Sq}$. Km. In the terms of area; Gondia district constitutes $1.83 \%$ of the total area of the Maharashtra State [11]. The study area GhatTembhani-Chipia covers about 14 sq. $\mathrm{km}$ areas with a population 4704 with average rainfall $1200 \mathrm{~mm}$. The study area mainly drained by Wainganga Perennial River in the North to West, North- East to North-West The Bagh Perennial River and South to North Pangoli River, which mainly non-perennial river as shown in Figure 1. Out of these the major cause of concern is the flood. It is solely responsible for the loss of life and property and casualties. About $10 \%$ of the population (119492 human lives) is affected by flood in the district as per the 2011 census [12]. A flood is an overflow of water in water bodies that submerges adjoining land. Floods occur in almost all rivers basins in India. The main causes of floods are heavy rainfall, inadequate capacity of rivers to carry the high flood discharge, inadequate drainage to carry away the rainwater quickly to streams/ rivers. Flash floods occur due to high rate of water flow as also due to poor permeability of the soil. Areas with hardpan just below the surface of the soil are more prone to, floods as water fails to seep down to the deeper layers. Approximately $33.3 \%$ of the total rain water goes as runoff, $33.3 \%$ is absorbed by the ground and another $33.3 \%$ gets evaporated and contributes to the precipitation. Thus, around $400 \mathrm{~mm}$ runoff takes place. The residents of Gondia District villages are used to the vagaries of the rivers. The main causes of floods in the region are rainfall more than $700 \mathrm{~mm}$, inadequate capacity of river channels to carry the high, flood discharge, inadequate drainage to carry away the rainwater quickly to rivers. 


\section{METHODOLOGY}

\subsection{Site Selection}

Site selection was done keeping in mind two types of flooding i.e. the natural floods and the man-made floods. The Ghat-Tembhni site was selected along the river course keeping in mind the intensity of floods in previous years. The entire river course along the northern border of the Gondia Tahsil has been identified. This is a part of the natural flooding which causes the maximum losses. Ground investigation interacted with the local people and brought preliminary knowledge about the conditions of the areas during and after rainfall every year. Survey the areas surrounding the river beds during the months of August and September, just after the rains.

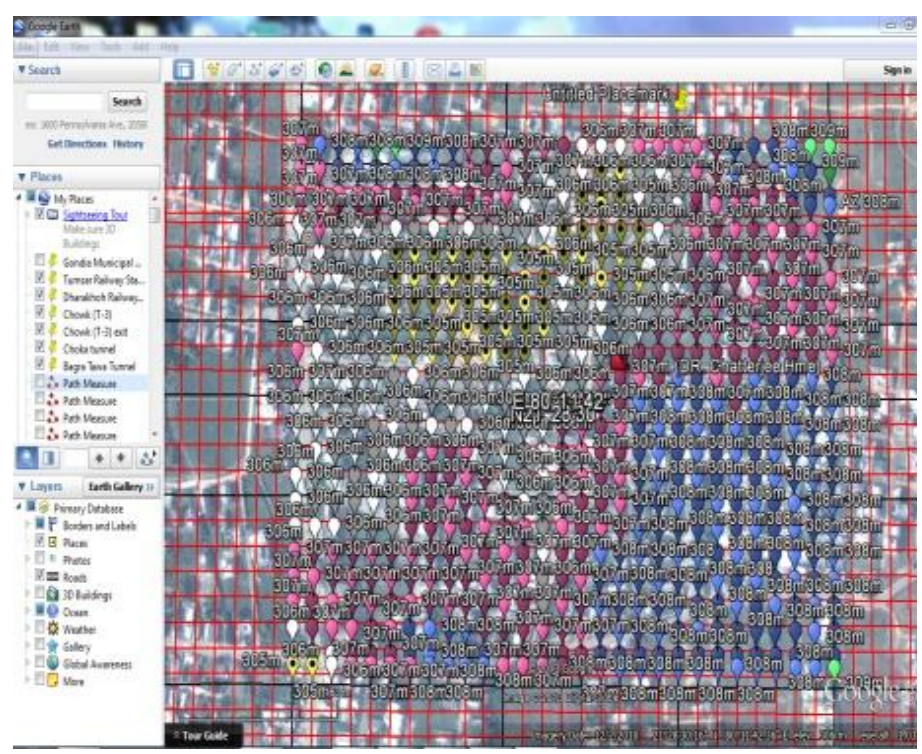

Fig 2 Shows plotting of grid on Google Earth and marking on WGS84 Contour level on each intersection on the grid.

\subsection{Grid plotting in Google Earth \& marking the}

\section{World Geodetic System (WGS 84) level at each \\ Point of Grid}

The sites were marked in Google Earth software with the latitudes and longitudes. In case of all the sites a particular area was marked and square grids were plotted. Thus each site covered a particular area which could be found out by the number of square grids in the area. In case of the areas surrounding river beds the grid size was 40x40m chosen. Thus the intersection of the grid lines gave a point. A particular area yielded numerous intersection points which formed a mesh like surface. These points were marked for the World Geodetic System (WGS 84) level [13] given by the Google earth software as shown in Fig.2.

\subsection{Contouring \& Digital Elevation Modeling in MATLAB}

The starting point of the selected site grid was taken as $(0,0$, 0 ) coordinates. From there the distance was taken in certain intervals in $\mathrm{x}$ and $\mathrm{y}$ direction, and the $\mathrm{z}$ coordinate was taken as the WGS 84 levels. Hence it formed a certain matrix in case of a certain area, giving each intersection of the grid points a unique set of coordinates. The data so processed was fed in MATLAB software through excel sheets. The contours line plots as well as the DTM was obtained by various set of programs. This gave a very refined analysis of the topography of the site selected and the defects could be visibly identified. This made the research outcomes lucid and easy to understand.

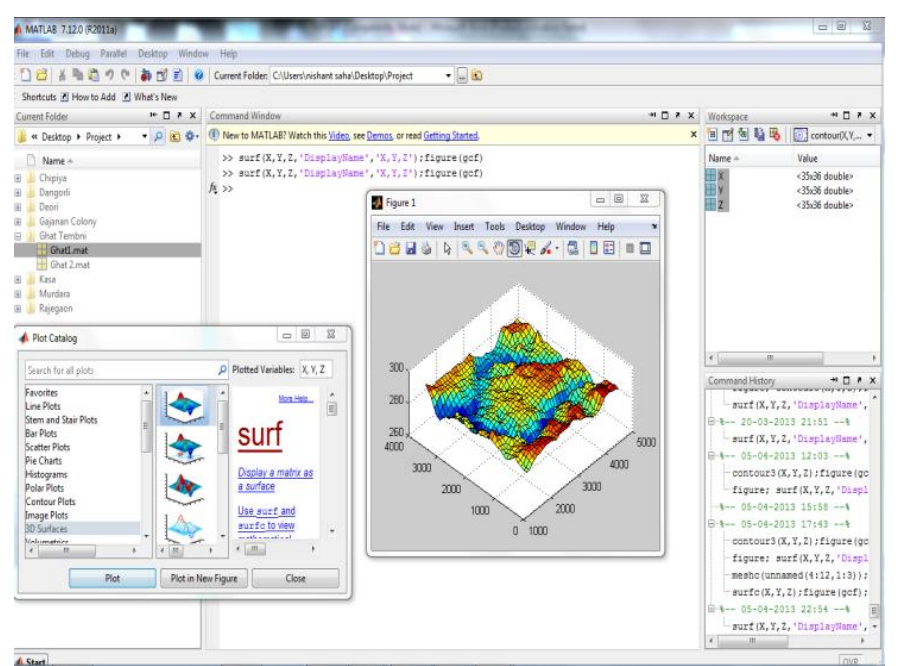

Fig 3 Showing plotting DTM of Ghat-Tembhni using MATLAB

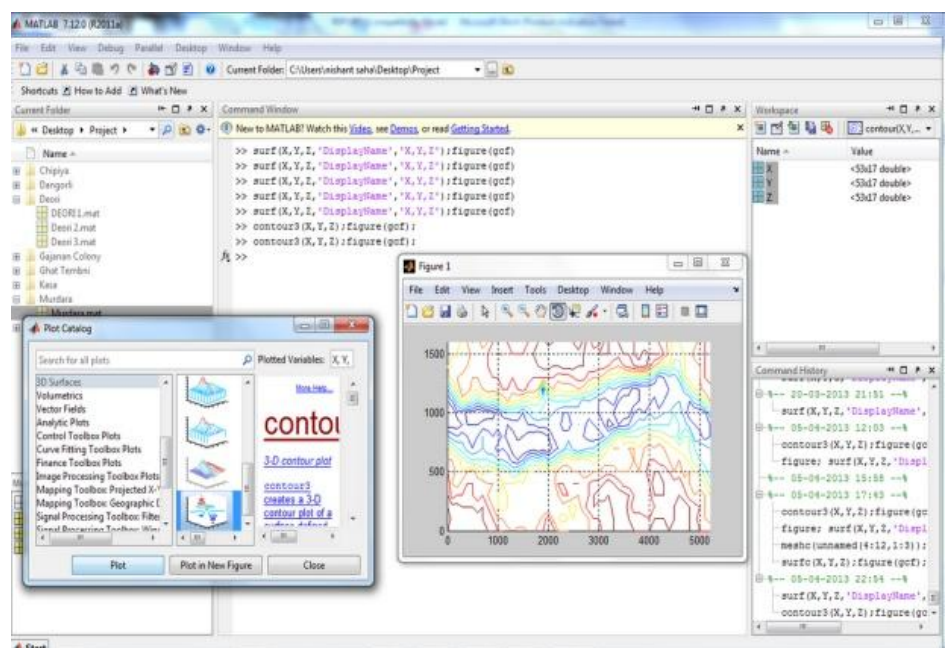

Fig 4 Shows plotting of Contour Map of Ghat Tembhni village using MATLAB

\section{RESULT \& DISCUSSION}

The area is bounded by the longitudes $80^{\circ} 17^{\prime} 27.19^{\prime \prime} \mathrm{E}$ and $80^{\circ} 19^{\prime} 23.49^{\prime \prime} \mathrm{E}$ and latitudes $21^{\circ} 34^{\prime} 16.25^{\prime \prime} \mathrm{N}$ and $21^{\circ} 35^{\prime} 59.94^{\prime \prime} \mathrm{N}$. The study area covers an area about 14 Sq.km. The villages Ghat Tembhni-Chipiya is situated north-east of the Tahsil place. The total population of the villages is 4704 as per census 2011. The Bagh River drains the area in the north from east to west. The maximum elevated point $296 \mathrm{Mt}$. WGS 84 level is situated in the center part of the study area and minimum elevation is 280 Mt. WGS 84 level as shown in the satellite image Figure 5. The Ghat Tembhani and Chipiya villages are situated at the 
confluence of The Bagh and Pangoli Rivers. The Pangoli River is the tributary of The Bagh River. The Ghat Tembhani is situated on the Right bank of Pangoli River where as Chipiya village situated on the Left bank of the Pangoli River. Ghat Tembhani and Chipiya villages are situated on the Left bank of the Bagh River towards the downstream side. The topography of the area is an undulating type and covers the alluvial soil throughout the area. As a result the land is very fertile and the main occupation of inhabitants is agriculture.

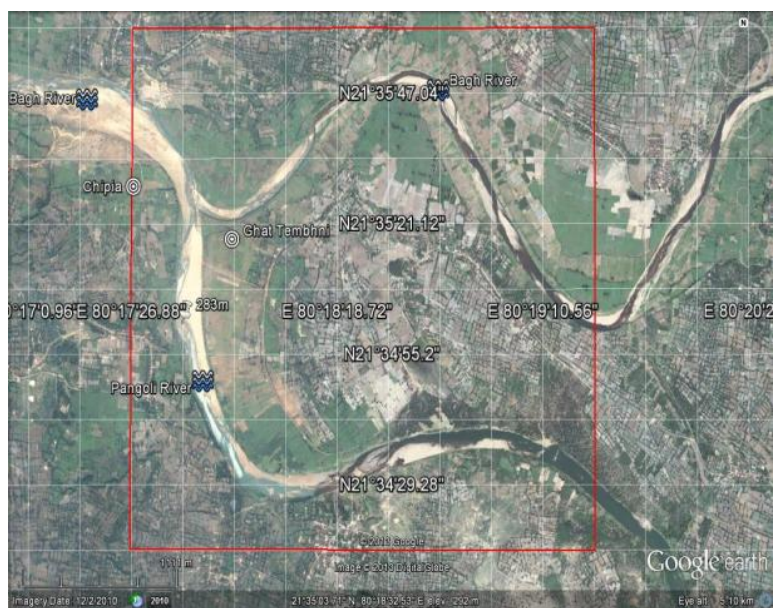

Fig 5 Satellite image of selected site of Ghat Tembhni and Chipiya villages, (Courtesy: Google Earth).

\subsection{Contour Map \& Digital Terrain Model of the}

\section{Area}

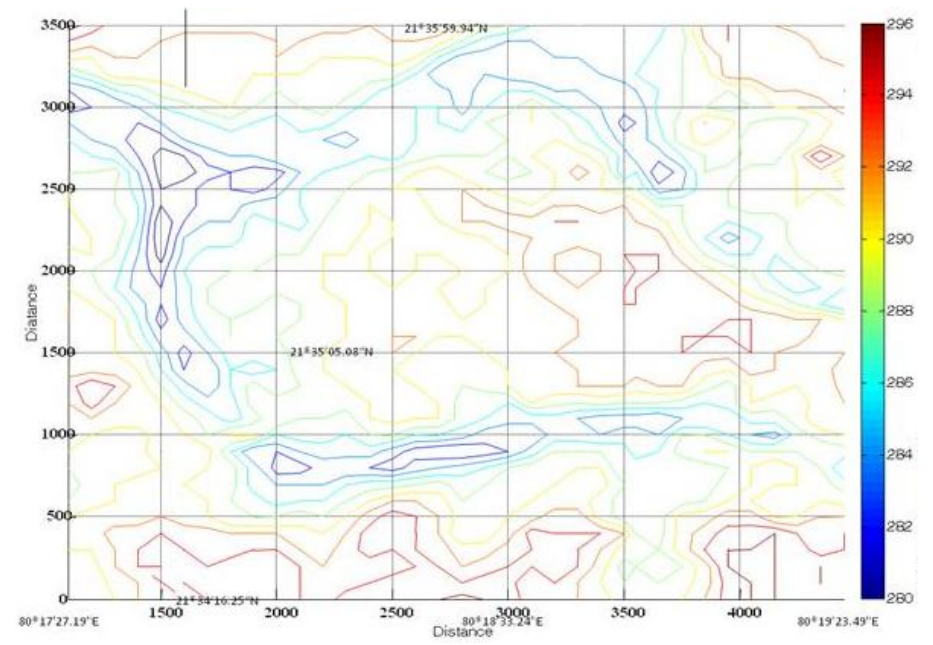

Fig 6 Detailed contour map of the Ghat Tembhni.

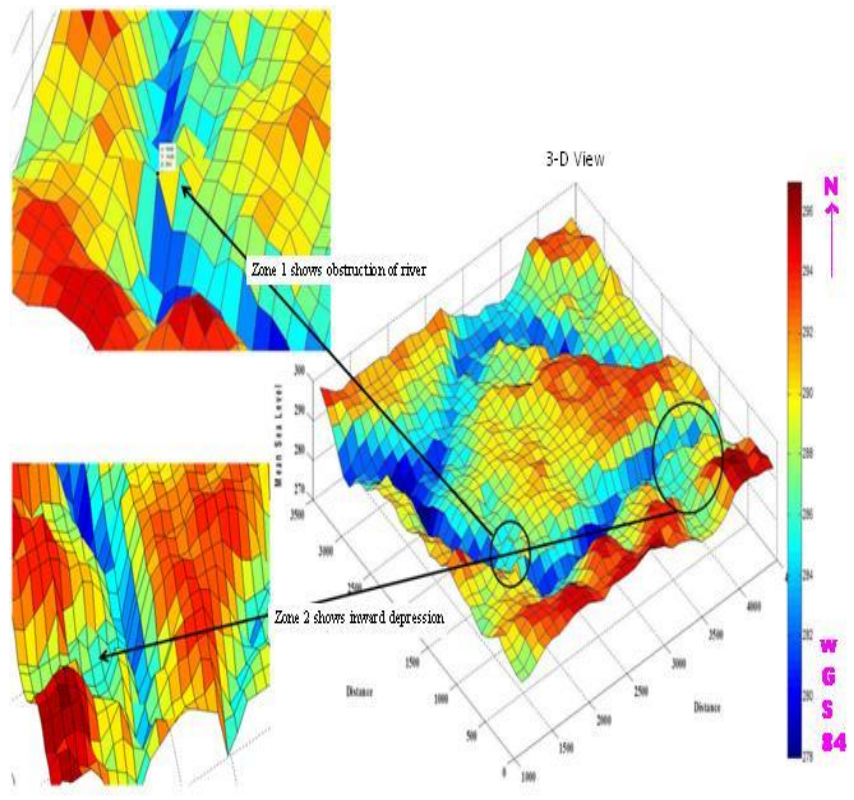

Fig 7 Digital Terrains Modeling of the Ghat Tembhni

\subsection{Causes of Flooding}

Ghat Tembhni is one of the villages that get very badly affected by the floods every year. The area can be described as Annually Flood Area (AFA). As there is confluence point of the Bagh and the Pangoli Rivers, the discharge is very high during the rainy season. The central area between the two rivers gets submerged almost every year. The discharge of Bagh River is very high and the water from Pujaritola, Shirpur and Sanjay Samovar Dams is also released during the rainy season. As a result the level of the water of Bagh River rises. Hence, a huge amount of water is drained by through the narrow channels of Bagh River. Pangoli on the other hand carries all the sewage and also the runoff water from the of the Gondia city. As a result the flux during rainy season is pretty high in this narrow natural drainage. The sand deposit is exposed at surface and about 40-50m wide. It contains coarse grained sand with rounded to surrounded pebbles. Bedding structure has also observed. At down slope the colluviums deposit comprises angular to sub angular boulders and rock fragments. From the contour map as shown in Figure 6 and DTM view as shown in Figure 7, we can infer that the reasons of flooding are due to:

1. There is a natural obstruction of approximately 4 meters (zone 1) along the course of the river forming a natural barrier. This stops the advancement of water in its natural course and hence water flows into the adjoining banks. The yellow and green portions of the $3 \mathrm{D}$ view as shown in Figure 7 show the areas which are most vulnerable to come under submergence in case of higher discharge in the rivers. This area floods heavily as there is convergence of two rivers and hence the flux is very high (WGS 84 value).

2. In Zone 2 there is an inward depression of the land along the left bank of the Pangoli River into the landmass. This area forms a narrow channel like terrain into the Chipiya village nearby. Hence there is an inflow of water into the subsiding areas. Also due to the natural barrier like 
formation in the river upstream, in rainy seasons the water tends to become stagnant in the zone and hence allowing a flow into the depression zone causing floods in the area.

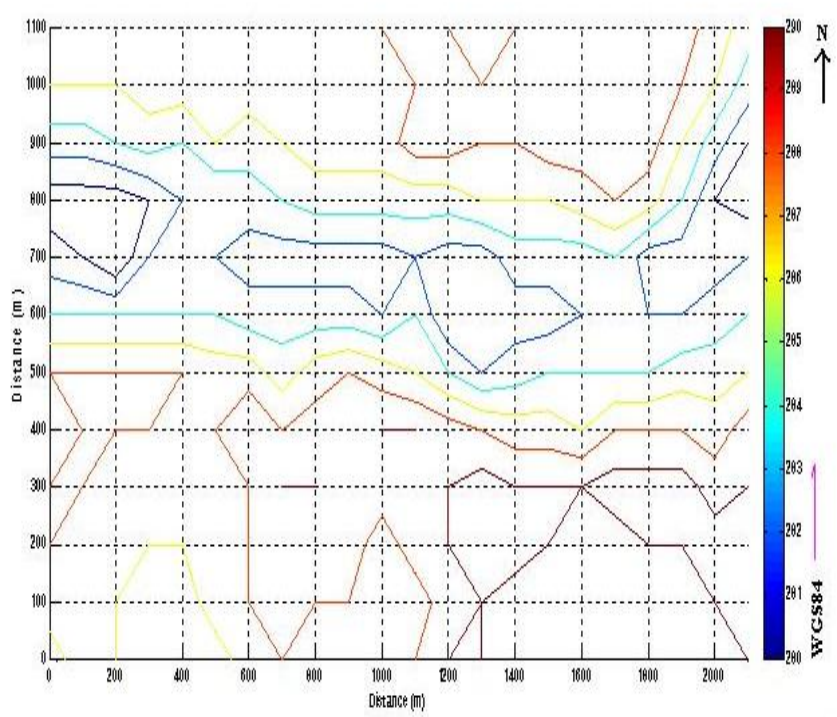

Fig 8 Detailed contour map of the Chipiya portion.

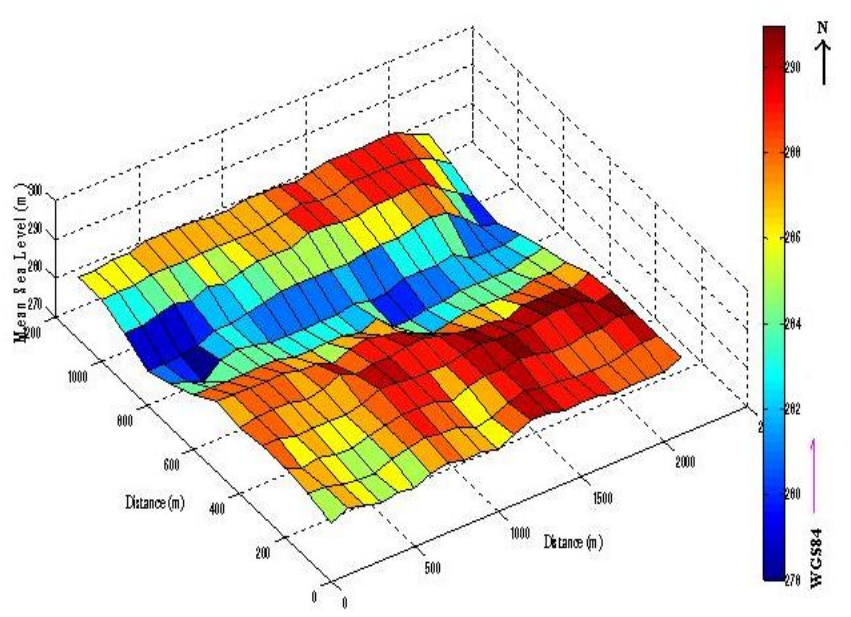

Fig 9 Digital Terrain modelling of the Chipiya portion

3. At the confluence of both the rivers namely Bagh and Pangoli, the flux of water is very high. Though the highest height of land is 291 WGS84 and the lowest level of river bed is 278 WGS84 i.e. the banks in the area as compared to the river bed are far high on the left as shown in Figure 8. But still as shown in Figure 8, the Chipiya village is affected by the high level of water as well as the back flow of the Pangoli River due to high discharge in the Bagh River. Thus, water flows into the left bank of the river. The Pangoli River is a tributary of the Bagh River. The Bagh River course will usually have the faster stream and will likely be the main navigation route for water. Water current is more in the Bagh River as compared to the Pangoli River. Due to this backwater flow takes place in the Pangoli leading to overflow of water from stream to the adjoining lands. Thus, when back water flows in this region it moves inwards leading to submergence as shown in Figure 9.

\section{CONCLUSIONS}

The proposed work shall identify the parameters related to natural disasters assessment of Gondia district from ecological perspectives. Possible efforts shall be focused to establish a relation between socio-economic and ecological balance for sustainable development. The work will identify and suggest the preventive measures to be adopted to protect from natural disasters in the study area. Natural disasters can be checked effectively which should establish the nature of relationship between the various parameters \& shall provide a mechanism for prediction or forecasting. Outcome of the study shall be helpful to suggest suitable treatment technology options to achieve sustainable development of Gondia district.

\section{REFERENCES}

[1]. Pandey Devendra, Shekhar Babu S. \& Singh R. P., (1998). Groundwater Vulnerability Map of Bhandara District, (M.S.), India, Proc. International Conference on Water Quality \& its Management, pp 452, New Delhi.

[2]. Pandey Devendra, Rathore S.S., Nashine A.L. \& Asati ,S.R., (2005). Environmental Protection Map of Bhandara \& Gondia Districts, (M.S.), India, Proc. 2nd International Congress of Chemistry and Environment, Journal of Chemistry \& Environment, Dec. 2005, New Delhi, P.P. 554-558.

[3]. Pandey Devendra, (2011). Environmental Vulnerability of Bhandara \& Gondia Districts of Maharashtra State, India", Proc. National Seminar on Water \& Environment, M. V. M., Bhopal, pp. 58.

[4]. Pandey Devendra, (2012), "Environmental Vulnerability of Bhandara \& Gondia Districts of Maharashtra State, India”, International Journal of Life Science Biotechnology and Pharma Research, ISSN 22503137. Vol.1, No.2, pp.20-30.

[5]. Pandey, Devendra, (2013),Surface Water Quality with Painstaking Human Impacts - A Case Study of the Wainganga River, Bhandara, Maharashtra, India, Int. J. Biossays, Vol 2, No 01, 272-277.

[6]. Pandey Devendra, (1999), Groundwater Vulnerability Maps of Bhandara District, (M.S.), India, Proc. International Conference on Water Asia'99, pp. 230-238, New Delhi.

[7]. Pandey, Devendra, Rathore S.S. (2011), Water Quality Assessment of Gondia \& Bhandara Districts of Maharashtra, India, Int. J. Res. Chem. Environ. Vol. 1 Issue 1, 114-118. [8]. Pandey Devendra, (2012), "Land Use and Land Cover Planning. of Gondia Municipal City, Maharashtra", International Journal of Life Science Biotechnology and Pharma Research, ISSN 2250-3137. Vol.1, Issue I, 47-57.

[9]. Pandey, Devendra, Ali Mir, Mubashir, (2013), Water Quality Index of the Wainganga River, Bhandara Maharashtra, India , International Journal of Civil, Structural, Environmental and Infrastructure Engineering Research and Development (IJCSEIERD),ISSN 2249-6866 ,Vol. 3, Issue 2, 115-124

[10]. www.gondia.gov.in accessed on 03 July,2014.

[11]. www.maharashtra.gov.in accessed on 23 July,2014.

[12]. www.census2011.co.in accessed on 23 July,2014.

[13]. www.ngdc.noaa.gov/geomag/WMM/newsoft.shtml 
accessed on 1 Sept.,2014.

[14]. Gazetteer of India, Maharashtra State Bhandara

District (Revised Edition), (1979).

\section{BIOGRAPHIES}

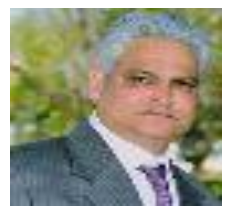

Devendra Pandey' Professor, Department of Civil Engineering, Manoharbhai Patel Institute of Engineering \& Technology, Gondia. India.

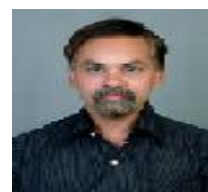

Dr. Yaswant B. Katpatal, Professor Department of Civil Engineering, VNIT, Nagpur, India

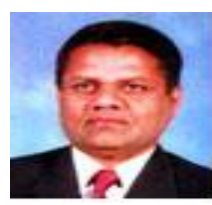

Dr.Pradeep P. Kundal, Professor \& Head, Dept. of Geology, RTM Nagpur University, Nagpur, India 